\title{
The Reciprocal Causation of the Eucharist and the Church: A Critical Analysis from Catholic Theological Perspective
}

\section{Francis Appiah-Kubi 1}

${ }^{1}$ Department of Religious Studies, Kwame Nkrumah University of Science and Technology, Kumasi-Ghana.

\begin{abstract}
The Catholic Church believes in the intrinsic and inseparable bond of the Holy Eucharist and the Church. In reference to its dogmatic Constitution, Lumen Gentium paragraph 11 (LG 11) the Church professes that the Eucharist, which is the body and blood of Jesus Christ, is "the source and summit of Christian life." Each of these two sacraments effects and builds each other. This implies that as the church celebrates the Eucharist, the members as they partake in the Holy Communion manifest concretely their unity and become one body of Christ. This article seeks to underscore the indissoluble reciprocal causality of the Eucharist and the Church, while it stresses on the Eucharist as the origin, the being, and the destiny of the Church. The study drums home critically the idea that the Eucharist builds the Church, and the Church makes the Eucharist. These are but two complementary terms, the Body of Christ, the Church which lives and continuously builds itself up through the Eucharist, Body of Christ. This great theological theme is one of the central points of deeper interest in Orthodox, Roman Catholic and Anglican ecclesiology. However, the paper examines critically the reciprocal causality between the Church and the Eucharist from the Catholic perspective as proposed by $\mathrm{H}$. de Lubac, a French theologian. It finally treats the interpenetration of the Eucharist as the Body of Christ and the Church as the Body of Christ from the perspective of sacramental theology.
\end{abstract}

\author{
Correspondence: \\ Francis Appiah-Kubi \\ Email: frkubi@gmail.com \\ Publication History \\ Received 8th September 2020, \\ Accepted 22nd September \\ 2020, \\ Published online 24th \\ September 2020.
}

Keywords: Eucharist, Church, Body of Christ, Interpenetration, Sacramental Theology, Reciprocal Causation.

(C) 2020 The Author(s). Published and Maintained by Noyam Publishers.

This is an open access article under the CCBY license (http://creativecommons.org/licenses/by/4.0/).

\section{INTRODUCTION}

Historically, in its doctrinal development, the Catholic Church has always honoured the Eucharist as the fulcrum and vital source of nourishment in its pilgrim journey towards the Kingdom of God to salvation. Since its foundation the Church has described the Eucharist as her indispensable source of utmost strength and development. This is in direct consonance with the Encyclical Letter Ecclesia de Eucharistia vivit (The church lives on the Eucharist) of John Paul II. Recognizing the Holy Eucharist as the mystery of faith, Pope John Paul II reiterates that the Holy Eucharist is the root of the Church's strength and development. ${ }^{2}$ He insists that the Church would be empty without the Eucharist; for it is her very life, and without the Church the Eucharist is meaningless, because it cannot be celebrated. ${ }^{3}$ As the Eucharist is believed to be the highest and the most sublime life of the Church, so it is believed that the two, the Church and the Eucharist are mutually non-exclusive.

Indeed, the Second Vatican Council had already referred to the Eucharist as "the source and summit of the Christian life." It affirms and re-affirms, according to Chito Arevalo, the mutual inclusivity of the Eucharist and the Church, ${ }^{5}$ in many parts of the Council's documents. ${ }^{6}$ The Second Vatican Council's teaching reminds us that from the altar of the Sacrifice of Christ the Church receives her strength and vitality. Just as the individual members of the Body

\footnotetext{
John Paul II, Encyclical Letter Ecclesia de Eucharistia vivit, (Roma, Editrice Vaticana, 2003), 1-2

John Paul II, Ecclesia de Eucharistia, 12

Lumen Gentium, 11

Chito Arevalo, The Eucharist and the Church, in www.clerus.org/dati/2002-03-25. Accessed 4-08-2020

Cf. $L G 3,11,26$; SC 10, 4; PO 6, 52.
} 
of Christ are strengthened and grow in holiness, above all by participation in the Holy Mass, so from the Eucharistic Sacrifice does the entire Body of Christ derive its life and development. ${ }^{7}$

In the same line of thought, the other sacraments and indeed all ecclesiastical ministries, according to the Catechism of the Catholic Church, are "bound up with the Eucharist and are oriented toward it. For in the blessed Eucharist is contained the whole spiritual good of the Church, namely Christ himself." It is the pivot around which the Church evolves and grows. As a result, the Second Vatican Council states in its Constitution on the Sacred Liturgy, Sacrosanctum Concilium that the Eucharist is the true center of the whole Christian life. It stresses that it is the summit of both the action by which God sanctifies the world in Christ and the worship which Christians offer to Christ, and through him to the Father in the Spirit. ${ }^{9}$

It is remarkable to note that the relationship between Christ and the Church is doubly decided. On one hand, Christ is associated directly with the Church, for the Church is built on Christ's salvific act on the cross and that Christ's suffering forms her life type. ${ }^{10}$ On the other hand, where the Eucharist is, according Cyprian of Carthage, there is the Church. Thus the Church is not only founded on Christ but also and at the same time has Christ as the one to whom it stands in relation and as the goal of its growth. ${ }^{11}$ In the same line of thought, and reflecting on the Church as a mystery, B. Bobrinsky argues that the Church is a realm of salvation permeating the cosmos, tangibly initiated by the death of Christ, and growing in a historical development toward the norm established in Christ, its head. ${ }^{12}$ Similiarly, Pope John Paul II points out clearly in his teachings that, "as often as the sacrifice of the Cross by which 'Christ our paschal is sacrificed' ( 1 Cor. 5:7) is celebrated on the altar, the work of our redemption is carried out, and at the same time in the sacrament of the Eucharistic bread, the unity of the faithful, who form one Body in Christ (cf. 1 Cor. 10:17), is both expressed and brought about." ${ }^{13}$ In his encyclical, John Paul II writes "The Church draws her life from the Eucharist."14 The Eucharist creates the Church, and the Eucharist is made and celebrated by, in and for the Church. According to Avery Dulles each one was created with a view to the other by God. There would be no one to celebrate the Eucharist unless there was a Church because when there is no Eucharist, the Church loses the ultimate source of her life. ${ }^{15}$

Effectively, Pope John Paul II observed "a causal influence of the Eucharist present at the Church's very origins." ${ }^{16}$ The Synoptic Gospels, specify that it was the Twelve Apostles, who gathered with Jesus at the Last Supper. ${ }^{17}$ This is a detail of notable importance, for the Apostles "were both the seeds of the new Israel and the beginning of the sacred hierarchy." 18 Through giving them his flesh and blood as food, Christ mysteriously includes them in the sacrifice that will later be completed at Calvary. The acts and words of Jesus at the Last Supper laid the foundations of the new Messianic community, the People of the New Covenant. The Apostles, by accepting Jesus' invitation in the Upper Room: "Take, eat," "Drink of it, all of you," ${ }^{19}$ entered into sacramental communion with him for the first time. From that time on, and by sacramental communion with the Son of God who was sacrificed for our sake, the Church is founded, ${ }^{20}$ up to the end of the age: "Do this in memory of me ... Do so, as much as you drink it and eat it."21

Furthermore, not only can we assume that each person receives Christ, but Christ also receives everyone. He enters into fellowship with us: "He that eateth me shall live by me" (Jn 6:57). Therefore, it follows that the power of the Church to "create" the Eucharist is entirely rooted in the self-gift of Christ to her. Here the significance of the words of Saint John is seen more clearly: "He loved us first." ${ }^{22}$ Indeed, the primitive Church's commitment to the "breaking of the bread" represents the fundamental importance given to the Eucharist by the first Christians for the growth of the Christian community. ${ }^{23}$ When the Church expanded, Christians began to devote themselves to the Eucharist. This account according to E. La Verdiere, was known and propagated everywhere by word of mouth and as a living truth by the early Church. A little later, it acquired a fixed liturgical form. ${ }^{24}$ Significantly, this account itself had often followed the celebration of the Eucharistic rite. It clearly does not in any way undermine its historical character, but it prevents us

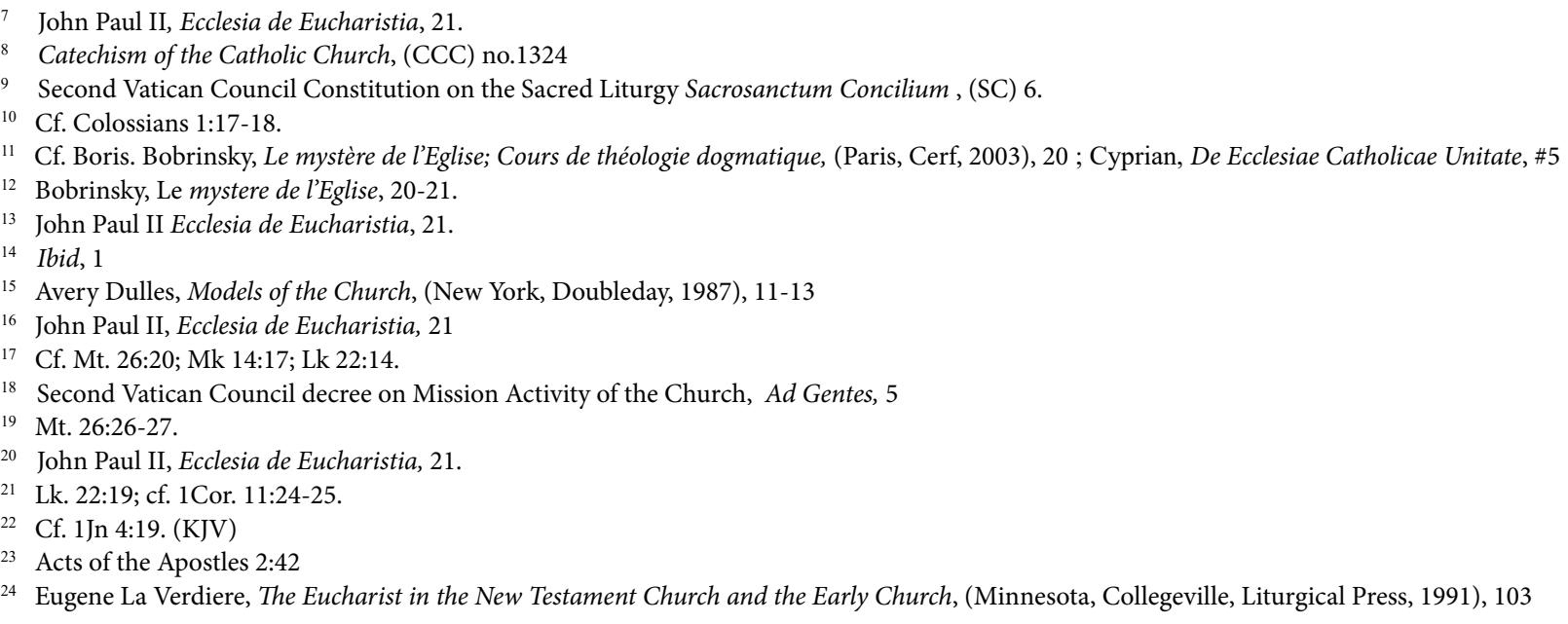


from dissociating the reality of the institution of the Eucharist from the sense given to it by the Church, from her living faith. This teaching according to J.O. Bonsu resonates with St. Augustine's view about the importance of the Eucharist that: "It is your own mystery that is set on the table of the Lord. This is your own mystery to accept in communion ... when you say 'Amen', you say 'yes' to what you are ... if you accept worthily, you are what you have received ... because the body of Christ is also on the altar and gathered together". ${ }^{25}$

\section{Overview of Henry de Lubac's Theology of the Eucharist and the Church: A Causal Relay}

H. de Lubac considers that there could be a causative relationship between the sacraments and the Church. He insists that the sacraments have a unitive function. ${ }^{26}$ For him just as the sacraments make real, renew or strengthen man's union with Christ, they also make real, renew or strengthen his union with the Christian community. ${ }^{27}$ Through the sacraments the unity of the Christian community is actualized and strengthened. For example, baptism incorporates the believer into the Body of Christ, the Church. Paradoxically, de Lubac argues that the sacraments, which are the instruments of the unity of the Church, are efficacious only in the corporate context. Thus, it has been said that the causality of the sacraments is to be found not so much "in a paradoxical efficacy but in the supernatural order of a rite or perceptible action, as in the existence of a society, which under the appearances of a human institution hides a divine reality." ${ }^{28}$

It follows logically that all the sacraments are simply Church sacraments; they achieve their full significance and effect basically in the Church. The sacraments are the instruments of grace by which the faithful are joined in Christ as Christ's ecclesial body, and yet the sacraments are only available in the Church. In this sense, de Lubac articulates his deep view of the Church's relationship: "through each one of us this one Church ever appears as the chief object as well as the chief minister of the sacraments; Sacramenta faciunt ecclesiam." ${ }^{29}$ In effect, de Lubac has described a causal relay in which the sacraments and the Church cause each other. For H. de Lubac, the Church and her sacraments intersect on the focal points of sacramental communion and the ecclesial communion: "For in the same way that sacramental communion is always at the same time an ecclesial communion, so also ecclesial communion always includes, in its fulfilment, sacramental communion."30

With regard to the Eucharist, this causal connection between the sacraments and the Church is strengthened in the sense that the Eucharist is the sacrament of reconciliation which makes the Church, and the Church is the body which makes or celebrates the Eucharist. In demonstrating that the Eucharist is the sacrament that makes the Church, de Lubac describes the Eucharist as the "sacrament of unity: sacramentum unitatis ecclesiasticae." 31 That is to say, the Eucharist has a unitive meaning, and the ecclesial body represents the unity of Christian believers through a common sharing in the Eucharistic bread. With reference to Cyprian, de Lubac argues that prioritizing the Eucharist as the sacrament which creates the unity of the Church is in line with the consensual patristic tradition and the early medieval era. ${ }^{32}$

Hence, the expression, Eucharistia facit ecclesiam, (The Eucharist builds the Church) in simplest terms indicates that the Eucharist renews in each Christian community and in every Christian life, the reconciliation and at-onemoment worked by God with himself, and the risen life of Christ Jesus, "poured out into our hearts", - all of this per

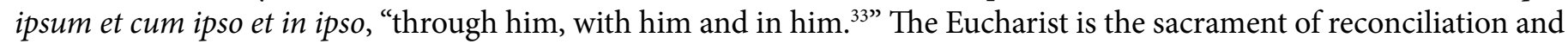
the bond of love in which Jesus makes himself "present to the people of every generation and enter their lives with the force of his love ... and is genuinely present in the Holy Eucharist as he was when he walked the streets of Jerusalem ... and in obedience to his desire, we are doing what Jesus did in memory of him." ${ }^{34}$

It is observed however, that de Lubac, does not consider the Church merely as the fellowship of the believers. He sees the Church in his definition of ecclesia mater as a clear, personal reality, with its own life apart from the believer. The relation, according to de Lubac between the Eucharist and ecclesiology means that the church cannot be established on the basis of legal standards alone (i.e. by analogy). ${ }^{35}$ Thus, everything points to a study of the relationship between the Church and the Eucharist, which may be described to each other as being standing as cause. The Church produces the Eucharist and inversely the Eucharist causes the Church to be and to grow. ${ }^{36}$ de Lubac should not be interpreted as meaning that the visible Church is an addendum to its existence as the Eucharistic spiritual body. The visible Catholic Church is then, for de Lubac, central to the validity of the sacrament. For him, a complementary relationship exists

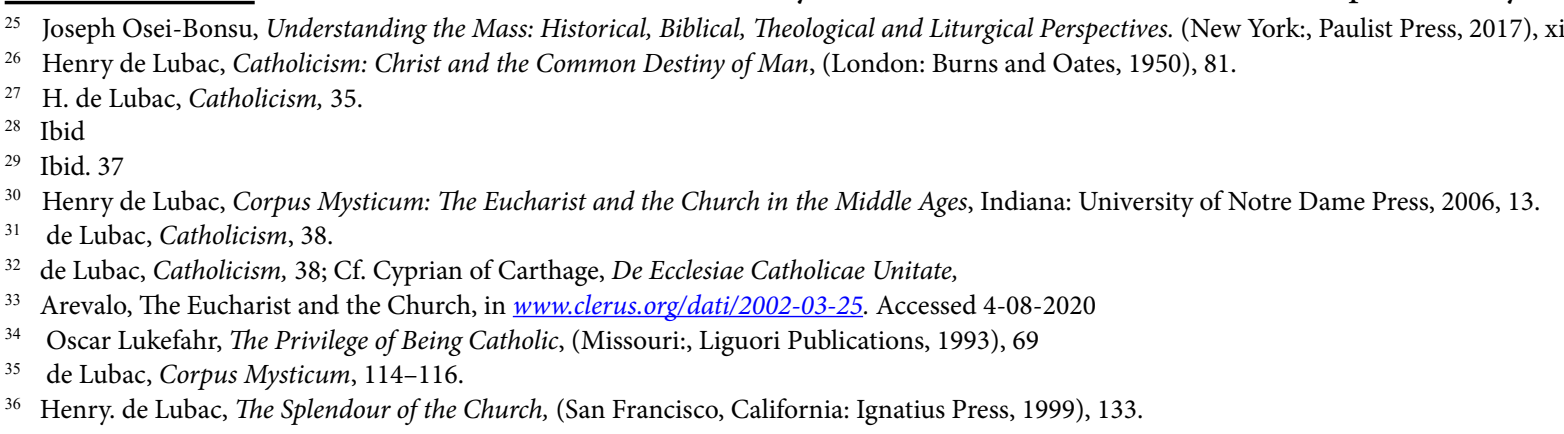


between the Church as the institution in which the Eucharist takes place and the Church as the body of Christ.

By emphasizing the connection between the Eucharist and the Church, particularly as regards the relationship between the Eucharistic body and the ecclesial body, de Lubac draws profoundly on a facet of Augustine's thinking. Particularly, de Lubac attributed Eucharistic significance to Augustine's sermon on the teaching of Jesus, "You shall not turn me into yourself as a bodily flesh, but you shall be transformed into me... I am your food, but instead of my being changed into you, it is you who shall be transformed into me;" they unhesitatingly understood that by their reception of the Eucharist the Christians would be incorporated the more in the Church. ${ }^{37}$

de Lubac understood Augustine to mean that by integrating Christ into himself or herself at the Eucharist, the believer would not turn Jesus' sacramental body into his own body, but rather be integrated into Christ's Body, that is, the Church. As P. McPartlan points out, it is obviously a platonic dynamic at work, in that the symbol (the Eucharistic elements) participates in the reality of the thing signified (the actual body of Christ). The Eucharist is properly the mystical body of Christ - the body of Christ in sacramental form..$^{38}$ The adherents are included in the true Body of Christ (the church) by obtaining the spiritual body of Christ, leading to the platonic notion that the recipient is integrated into what has been received. ${ }^{39}$

In other words, it is in the celebration of the Eucharist that the community of Christ's ecclesial body is created, and Christ's presence is real in the Eucharist, for the ecclesial body is created by the participation of the spiritual body. Such a reflection leads de Lubac to define the church as the sacrament's actual res ultima (ultimate reality). ${ }^{40}$ In this sense, as the body brought into being, it was, de Lubac contends, natural to identify the Church as the corpus verum, the true Body of Christ. ${ }^{41}$ Therefore, de Lubac interprets Augustine as having conceived of the appellation "the Body of Christ" as instantly one, but operating on several interconnecting levels, lubricated by symbolic inclusions: First, the historical body of Christ born of the Virgin Mary, second, sacramentally present in the Eucharistic elements (the mystical body,) third, believers incorporate, and through incorporating the mystical body of Christ are assimilated into the ecclesial Body of Christ (the true body). ${ }^{42}$ Accordingly, the Eucharist as the mystical Body of Christ has a pronounced ecclesial significance, and the church as the ecclesial Body of Christ has an intrinsically Eucharistic character. ${ }^{43}$

Nevertheless, in his book, Corpus Mysticum, de Lubac remarks and criticizes what he considers theological obscurantism of such symbolic inclusions. He conducts his thesis through a historical examination of the term "the Body of Christ," noting how its coherent and triple character as political, sacramental and ecclesial began to disintegrate into an ever greater phenomenon in an attempt to differentiate and define the different levels of the corpus triforme ${ }^{44}$ resulting in inflexible definitions incompatible with the fluidity of the Augustinian symbolic model. ${ }^{45}$ As a result, the church as the ecclesial body was not understood in relation to the Eucharist, but rather as analogous to juridical or political bodies, ${ }^{46}$ leading to the conceptual separation of the Eucharist and the Church. ${ }^{47}$ This condition was compounded by the characterization of the Eucharist itself as the true Body of Christ, which led to the Eucharist being seen as the supreme moment of the ecclesial assembly, in which the Church existed for the sake of celebrating the Eucharist, rather than the Eucharist and the Church which existed in mutually causative union. However, both the Church and the Eucharist are the same body of Christ. ${ }^{48}$ The Church celebrates the Eucharist. This is the basic reality. The Church in its celebration of the Eucharist makes present the sacrifice of the Body and Blood of Jesus.

\section{The Eucharist in the Life of the Church}

The Church makes the Eucharist, Ecclesia facit eucharistiam: Indeed, if the Word is not announced (cf. Rom. 10:14-15), and if no one celebrates the remembrance of the Passover of the Lord in the sacrament, in obedience to the order of the Lord, then in time and place there is no Eucharist realized. The Eucharist requires the Church's ministerial service, for its realization. This ministry is what gathers the people, proclaims the Word, and breaks the bread; it was the practice among the early believers in the apostolic Church, Acts 2:42 - 46 .

\footnotetext{
de Lubac, Catholicism, 99-100. See Augustine, Confessions, 7, 10, 16.

38 de Lubac, Corpus, 249-250.

P. McPartlan, The Eucharist Makes the Church, 4.

de Lubac, The Splendour, 132-133.

1 de Lubac, Corpus Mysticum, 189.

Ibid. 61

Ibid. $23-28$

44 The three forms of the Body of Christ: 1 . The soma typicon (coined by Origen, the typical body, ie, the individual body of the man Jesus.) 2 . The corpus mysticum, which is referred to as the Eucharistic body, ie, the communion bread, but then was later refer to the corpus Christi quod est Ecclesia, the body of Christ which is the Church. 3. The corpus verum thus the true body which originally referred to the body of Christ which is the Church but then was demoted to refer to the communion bread.

45 de Lubac, Corpus Mysticum, 267.

46 Ibid. 114-116

47 Ibid. 75, 102-104.

48 de Lubac, The Splendour, 157
} 


\section{- Ministerial perspective}

Pope John Paul II, in his encyclical letter, reaffirms unhesitatingly the teaching of the Second Vatican Council on the Eucharist as the centre and summit of the Church's life, ${ }^{49}$ and confirms that it is likewise the centre and summit of priestly ministry. For this reason, the Eucharist "is the principal and main raison dêtre of the sacrament of priesthood, which effectively came into being at the moment of the institution of the Eucharist." ${ }^{50}$ Accordingly, in the Second Vatican document Presbyterorum Ordinis, on The Life of Priests, it is stated that "no Christian community is built up that does not grow from and hinge on the celebration of the Most Holy Eucharist." ${ }^{11}$ The Eucharist demands its realization, the Church's ministerial service. During the Last Supper, Jesus inaugurated the Eucharist and the hierarchy. We can thus, agree with Pope John Paul II who in Ecclesia de Eucharistia, reiterates that the Last Supper meeting was the beginning of the Holy Hierarchy under which Christ instituted the ministerial priesthood, ${ }^{52}$ Acting in persona Christi $i^{53}$ priests, are not only ordained for the ceremonial or sacramental service alone, but also to serve as consecrators of the Holy Eucharist and the universe. ${ }^{54}$ The assembly gathered for the celebration of the Eucharist includes the presence of an ordained priest as its president and as the gift of God which the assembly receives, if it is to be a genuinely Eucharistic assembly. ${ }^{55}$

The ultimate exercise of the power of the Hierarchy, H. de Lubac claims is to consecrate the Eucharist and thereby perpetuating the task of salvation. The priest acts in the name of the entire world at the Eucharistic celebration and the human and spiritual are joined in a mystical manner. ${ }^{56}$ de Lubac identified the authority and teaching capacity of the hierarchy which is the proclamation of the Word of God, within its priestly power of sanctifying, and especially within the celebration of the Eucharist. ${ }^{57}$ The principles that the Church and the Eucharist are caused reciprocally takes place via the presence of Christ in the Eucharist. The members of the hierarchy bring about the presence of Christ and simultaneously receive Christ with others in the Eucharist. ${ }^{58}$

\section{- Eucharist; the seed of a new messianic community}

From the above it can be confirmed that the Church realizes and effects the Eucharist and that conversely the Eucharist makes the Church, rendering it as sacrament of Christ, sign and means of the communion that God wants with all people. ${ }^{59}$ The Eucharist turns the Christian community into an assembly that listens to the Word and converses with its Lord, a family community at the service of all brothers and sisters in Christ and even beyond, always evangelizing and Missionary focused. Hence, Ecclesia de Eucharistia affirms that the actions and words of Jesus at the Last Supper laid the foundations of the new messianic community, the people of the New Covenant, ${ }^{60}$ seeds of the New Israel ${ }^{61}$ and the family of God. ${ }^{62}$

The messianic community's spiritual existence is incorporated in Christ. This is the initiation into Christ's body that makes one a part of God's new creation. It is the death and resurrection of Christ which has set forth the new people. Christ specifically gave His death at the Last Supper the sense of Himself to God for all. It was a true reconciliatory sacrifice which restored the covenant with God. The passion, argues K.B. Osborne, sanctifies humanity, reconciles, creates harmony, redeems, sets up the Church, and thereby unites human beings in fellowship with God and with one another. ${ }^{63}$ The Church then becomes God's new people who reside in the form of Christ's body. In simple and paradoxical terms, it can be concluded that it is by eating the body of Christ that we become the body of Christ, the Church. Arevalo could intimate that the "Eucharist therefore renews in each Christian community and in every Christian the reconciliation and the at-one-ment worked by God"64 through Jesus Christ.

\section{- The Eucharist: Source of Communion}

The understanding of the Eucharist as fundamental to the life of the Church is well expressed in the new ecclesiology of

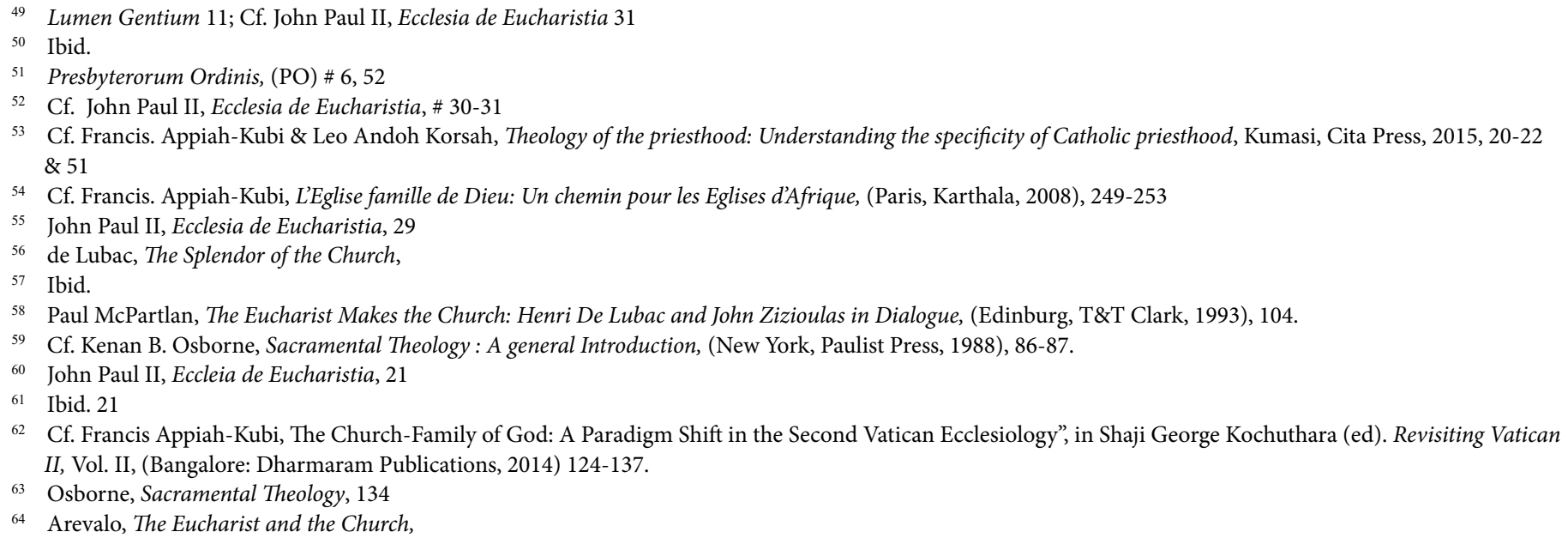


communion of the Second Vatican Council. The Conciliar Fathers thus describe the relationship between the Eucharist and the Sacred Body as follows: "In truly sharing in the breaking of the Eucharistic bread, we are taken up into communion with him and with one another." ${ }^{\prime 5}$ The community's new life, formed together through the breaking of the Eucharistic bread, is communion with God by listening to his Word and living through brotherly love, exchanging both the spiritual and the material goods. The Church is the location where there is a Eucharistic assembly. Without a Eucharistic assembly, the Church cannot exist; and the Eucharistic assembly can do nothing but manifest the plenitude and the unity of the Church. Hence the structure and the order of the Church come from the Eucharistic assembly, ${ }^{66}$ which contains the whole basis of ecclesial organization. Insofar as it possesses Christ entirely, every Eucharistic community is already, in se, the Church.

The regular gathering for the Eucharist revitalizes communion of the faithful with Christ and with one another through the sacramental connection of the one word and prayer, and particularly through the one bread and one chalice. This demonstrates a great significance of celebrating the Eucharist in the Church as the center of communal life for all Christians. L. Chiara asserts: Christ unified Christians with himself and with one another through the Eucharist into one Body which is his own. As a result, he gave the Church her most intimate and essential life. The Church is Christ's Body and is a representation of brotherhood, unity of life and communion with God. Therefore, the Eucharist builds the Church, and not only a part of it but the entire Church. ${ }^{67}$

The Church, which was established as the new community of the People of God, in the apostolic community of the Twelve who became partakers of the Body at the Last Supper, entered into Sacramental Communion with the Son of God, a Communion which is the promise of eternal life. From that moment until the end of time, the Church is being built up in the same communion with the Son of God, a communion that is the promise of eternal life. ${ }^{68}$

Commenting on the Pauline epigraph Unus panis, unum corpus sumus multi - "We who are many are one flesh, and we all eat the same bread" (1 Cor 10:17), J. Ratzinger affirms rightly by insisting that, Christian unity is what occurs in the Eucharist. Hence the Eucharist can be thoroughly understood from a diverse ecclesiological perspective. The Eucharist, in this sense, brings Christians from their state of dispersion into the unity of the one bread and the one body ${ }^{69}$ He reiterates: "The Church is the Eucharistic Fellowship, a network of Eucharistic Fellowships, and in the one body that all believers receive, she is unified, again and again." ${ }^{70}$ Here the Eucharist's main focus becomes clear. The Eucharist is instrumental in the process whereby Christ builds himself a body and makes all Christians one bread, one flesh. It is the living process in which the operation of the Church to become the Church happens time and time again. By expressing himself to people, entering into communion with them and thereby bringing them into communion with one another, Christ offers humanity life in abundance. ${ }^{71}$ The Church originates, and has her continuing existence, in the Lord's communicating himself to men and women, entering into communion with them, and thus bringing them into communion with one another. The Church is the Lord's communion with us, which at the same time brings about the true communication of human beings with one another. ${ }^{72}$

\section{- The Eucharist, The Heart of the Church}

The enigmatic nature of the Church is given full expression in the Eucharist. ${ }^{73}$ The Church then takes on the features of the great mystery of faith by immersing herself in the Eucharist. This idea is clearly articulated in Lumen Gentium: "Once we receive Holy Communion, we let Christ into our hearts to make them his." ${ }^{4}$ The Eucharist is the heart of the Church, where the Eucharistic life thrives, the Church flourishes and grows. N. Halligan could then attest and confirm that "the Eucharist is the source of perfecting the Church, fashioning it into the true community of the People of God, into a congregation of believers, sealed with the same mark of unity that the first Apostles and disciples of the Lord shared." 75 He continues to argue that the "Eucharist builds ever anew this community and unity and thus the church lives by the Eucharist, by the fullness of the sacrament." ${ }^{\prime 6}$ There is, in one way, no distinction between Church and Eucharist. It does not mean that Christians have no other profession outside the celebration of the Eucharist but merely that the latter shows the Church's fullness in that it is an important symbol due to the religion it represents. They take care of the fullness of life in Christ in the Eucharist. Through expectation, it is true, but not partially, and this is conditional on total

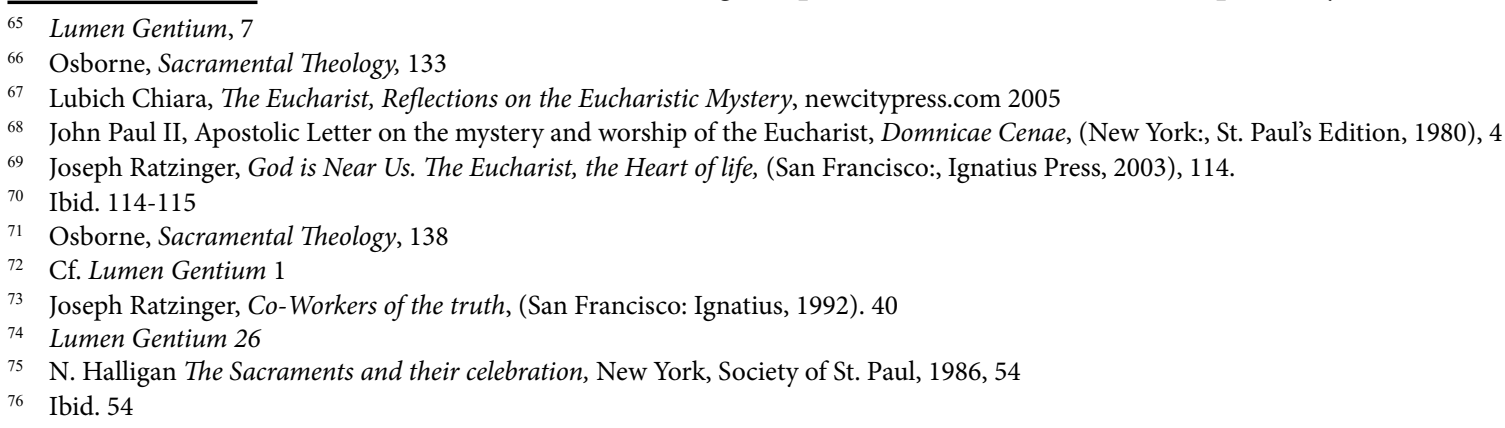


commitment on humanity's side. The mystery of Christ's Body and Blood has meaning only in its fullness: the body and soul of the entire Church and of all of us individually and collectively.

\section{CONCLUSION}

The Church contains the Eucharist and builds its life by celebrating the Eucharist. Each celebration of the Eucharist contributes to the growth of the Church, to the development of its holiness and to the strengthening of its unity. The Eucharist is the center and heart of the Church, the expression of our present communion in the Body and Blood of the risen Christ-with all humanity and the whole universe. If it can be said that the Eucharist makes the Church then all believers should readily understand that the Church itself is a family of Eucharistic communities, a communion of local churches, which was the patristic model. Consequently, the Eucharist is the root, nucleus and pinnacle of the Trinitarian life of the Church, the very heart of both her communion and mission. Both the Church and the Eucharist effect and cause each other reciprocally. Both are divine gifts from Christ and they exist purposively for each other.

\section{ABOUT AUTHOR}

Very Rev. Fr. Dr. Francis Appiah-Kubi is a Senior Lecturer at the Kwame Nkrumah University of Science and Technology, Kumasi, Ghana, former Head of the Department of the Religious Studies Department at the Faculty of Social Science in the KNUST is currently Chairman of Tender Evaluation Panel (Goods and Services-Procurement). He is a Ghanaian Theologian specialized in Ecclesiology and studies in African Traditional Religions.

\section{BIBLIOGRAPHY}

Appiah-Kubi Francis, The Church-Family of God: A Paradigm Shift in the Second Vatican Ecclesiology", in Shaji George Kochuthara (ed). Revisiting Vatican II, Vol. II, (Bangalore: Dharmaram Publications, 2014) 124-137.

Appiah-Kubi Francis, L'Eglise famille de Dieu: Un chemin pour les Eglises d'Afrique, (Paris, Karthala, 2008), 249-253

Appiah-Kubi Francis \& Andoh Korsah Leo, Theology of the priesthood: Understanding the specificity of Catholic priesthood, (Kumasi, Cita Press, 2015)

Bobrinsky, B., Le mystère de l'Eglise; Cours de théologie dogmatique, Paris, Cerf, 2003.

Flannery, Austin. (Gen. Ed.). Vatican Council II: The Conciliar and Post Conciliar Documents. (Vol. 1, New Rev. Edition), NY: Castello Publishing Company, 1975.

Halligan N. The Sacraments and their celebration, (New York, Society of St. Paul), 1986.

John Paul II, Encyclical Letter on the Eucharist in its Relationship to the Church, Ecclesia de Eucharistia, (Roma Editrice Vaticana), 2003. , Apostolic Letter on the mystery and worship of the Eucharist, Domnicae Cenae, (New York:, St. Paul's Edition), 1980.

de Lubac, Henri. Catholicism; Christ and the Common Destiny of Man. (London: Burns and Oates), 1950. , Corpus Mysticum; The Eucharist and the Church in the Middle Ages, (Notre Dame, Ind. University of Notre

Dame Press), 2006. , The Splendour of the Church. (San Francisco, Calif.: Ignatius Press, 1999). Eucharist Makes The Church (Part 1), (London, 2005), www.zenith.org on, Accessed May 12, 2020.

McPartlan, Paul. "The Body of Christ and the Ecumenical Potential of the Eucharist," Ecclesiology (2010) , The Eucharist Makes the Church: Henri De Lubac and John Zizioulas in Dialogue, (Edinburg, T\&T Clark, 1993).

Moloney, Raymond, "Henri de Lubac on the Church and Eucharist," Irish Theological Quarterly 70, (2005): 331-342. https://doi.org/10.1177/002114000507000402

Osei-Bonsu, Joseph, Understanding the Mass: Historical, Biblical, Theological and Liturgical Perspectives. (New York, Paulist Press, 2017).

Osborne, B. Kenan, Sacramental Theology: A General Introduction, (New York, Paulist Press 1988)

Ratzinger, Joseph, Co-Workers of the Truth, (San Francisco: Ignatius, 1992). , God is Near Us. The Eucharist, the Heart of life, (San Francisco: Ignatius Press, 2003).

La Verdiere, Eugene, The Eucharist in the New Testament Church and the Early Church, (Minnesota, Collegeville, Liturgical Press, 1991). 